\title{
Sustainability Activities In The Mining Sector: Current Status And Challenges Ahead Limestone Mining In Nusakambangan
}

\author{
Theresia Vika Ayuningrum $^{1 *}$ and Hartuti Purnaweni ${ }^{2}$ \\ ${ }^{1}$ Master Program of Environmental Science, School of Postgraduate Study Diponegoro University \\ ${ }^{2}$ Public Administration Dept, Faculty of Social and Political Science, Diponegoro University
}

\begin{abstract}
Potential Karst area in Nusakambangan has an important role in maintaining the balance of nature. But with the existence of mining activities, will automatically change the environmental conditions there. In order for the utilization of resources to meet the rules of optimization between the interests of mining and sustainability of the environment so in every mining sector activities required a variety of environmental studies. The purpose of this study is to find out how the analys is of environmental management due to limestone mining activities in Nusakambangan so that it can be known the management of mining areas are optimal, wise based on ecological principles, and sustainability. In qualitative research methods, data analys is using description percentage, with the type of data collected in the form of primary data and secondary data.
\end{abstract}

\section{Introduction}

The mining industry has a marked influence on the economy of several countries, mostly through job creation and cascading effects on other sectors. However, mining activities often have major environmental impacts that incur long-term costs for governments. In response to mounting criticism, the mining industry has paid increasing attention to the environmental and social impacts of its activities, notably by embracing the concept of sustainable development [1]. However, the capacity of the mining industry to be sustainable is often contested [2], mostly because non-renewable resources are exploited [3]. Moreover, while civil society considers sustainable development a necessity, industries such as mining still largely see it as a compromise [4].

Adopting sustainable development principles can be a major challenge for the mining industry [4,5]. Important efforts have been made to better take into account environmental and social issues across the sector $[6,7]$. These issues are increasingly mentioned in the sustainable development reports published by mining companies[8,9,10]. However, the efforts of mining companies to ensure that their activities are respectful of the environment and society are often below the expectations of the population $[11,12,13]$.

Limestone mining on Nusakambangan Island has been done by PT Holcim Indonesia Tbk (formerly PT Semen Nusantara) since 1977 ago. This activity is done to get limestone as raw material of cement making. This study aims to determine the physical environment changes due to limestone mining and to know how the activities of sustainable environmental management post mining. This research uses descriptive qualitative method based on interview result and direct observation in field and supported by secondary data. The results of research conducted in several regions indicate that limestone mining activities have a negative impact, such as the formation of very precipitous slopes that are very dangerous, air pollution, the number of open land, the decrease of the flow of water springs. Nevertheless, mining activities are still running because mining activities also have a positive impact on the original revenue $(\mathrm{PAD})$ Cilacap regency.

\section{Sustainable Indicators}

The minerals industry is often divided into four subsectors: Energy minerals (e.g. coal, oil); Metallic minerals (e.g. iron, copper, zinc); Construction minerals (e.g. natural stone, aggregates, sand, gravel, gypsum), and Industrial minerals (e.g. borates, calcium carbonates, kaolin, plastic clays, talc). Although these four subsectors share many common characteristics with regard to sustainability issues, they are also quite different. For example, a key issue associated with the use of energy minerals is depletion of nonrenewable resources. Other minerals on the other hand are (strictly speaking) not depleted, but dissipated in use and can (at least

Corresponding author: vikaayuningrum89@gmail.com 
theoretically) be recovered and reused. These and other differences require a particular care in the development of an appropriate set of sustainability indicators that, in turn, is contingent upon identification of the key sustainability issues that are relevant for an industrial activity. In the development of the indicators proposed here, the emphasis has been on the key issues relevant to three mineral sub-sectors: metallic, construction and industrial minerals.

\subsection{Economic indicators}

Economic indicators measure economic impact of a company on its internal and external stakeholders and on economic systems at the local, national and global levels. Therefore, the economic indicators need to include the usual measures of financial performance such as profits and shareholder returns, but also to go beyond the traditional fiscal indicators to reflect the wider contexts in which companies operate. The economic indicators within this framework are based on the five GRI categories of performance each comprising a number of specific indicators such as net sales, return on investments and taxes paid to the public sector.

In addition to these, as indicated, it has been necessary to add two more types of indicator, related to products (e.g. value added) and local communities (e.g. revenue distribution). This makes the information provided under this category more transparent and compatible with the way the environmental and social indicators are presented. The categories of economic indicators proposed within this framework are summarized, which shows the type of information provided by each indicator category as well as the economic issues and stakeholders they affect. The full list of economic indicators. All together, 24 economic indicators have been proposed, of which six are additional to those proposed by the GRI. The additional indicators include generally-applicable measures of economic performance such as earnings before interest and tax (EBIT) as well as the sector-specific indicators, such as total investments for mine closure and rehabilitation.

\subsection{Environmental indicators}

Of the three types of sustainability indicators, environmental measures of performance are most developed and have achieved the highest degree of consensus among experts. They measure a company's impacts on natural systems, including humans, ecosystems, land, air and water. These impacts can be local, regional or global thus affecting a wide range of stakeholders. For example, depletion of minerals resources has both local and global implications. Locally, it will affect the employees and their job prospects as well as the local communities' prospects to benefit in the longer term from mining activities. Globally, depletion of minerals reserves affects both the current and future generations, as they can no longer rely on these resources to satisfy their needs.
It is therefore important that the environmental indicators reflect not only the key environmental issues but also the scale of magnitude of the impacts. This can be achieved by using both the absolute measures of environmental performance (e.g. tonnes of mineral resources extracted per year) and normalized units (e.g. tonnes of a mineral resource depleted per year relative to the world reserves of that resource). Normalized units also enable comparisons between companies of different sizes, particularly if they are expressed per tonne of product.

As discussed earlier, another important aspect in developing the environmental indicators is life cycle thinking which provides a holistic approach required in addressing sustainable development. The life cycle approach is particularly useful for the identification of 'hot spots' in the supply chain as it shows the most important stages and impacts in the life cycle so that they can be targeted for maximum improvements. Life cycle assessment (LCA) is the usual tool used for quantification of environmental impacts of products and processes along the supply chain.

However, it is appropriate to make a distinction between the scope of the analysis for mineral products and mine facilities. Given a myriad of uses that most minerals are put to, in most cases it would be impossible for mineral companies to follow all their products from 'cradle to grave'; instead, a reduced, 'cradle-tocustomer' scope may be more suitable but also more practical. This includes all activities along the supply chain, from extraction to delivery of the mineral product to the customer. However, in cases where companies are also involved in the recovery of waste products, a full 'cradle-to-grave' approach should be taken. For the mine and processing facilities, however, the full 'cradletograve' approach must be taken, encompassing design, operation, decommissioning and rehabilitation.

\subsection{Social indicators}

While the economic and environmental performance are relatively easy to measure and the indicators are generally well developed and agreed upon, measuring the level of social sustainability of a business or a sector is not an easy task. One of the reasons is that social indicators must take into account the many interests of both employees and those of the wider communities to reveal company's social impacts at the local, national and global levels. Furthermore, in social and ethical dimensions of a company's activity, many of the variables such as protection of human rights or cultural values are hardly quantifiable, and cannot even be defined in physical terms [14]. Yet, without addressing these issues, the assessment of sustainability would not be complete.

Therefore, the set of social indicators proposed within this framework has been designed to include both qualitative and quantitative indicators, as appropriate. Following the GRI framework, they have been grouped into five categories, related to labour practices, human rights and broader issues affecting consumers, local 
communities and other stakeholders..The GRI recommends the use of 53 different social indicators. This number has been reduced to 45 in the framework proposed in this paper as some of the GRI indicators are more appropriate for companies in the consumer products sector rather than to the mining and minerals industry.

\section{Overview Of Nusakambangan Island}

Nusakambangan Island is located in the south of Java island and is the outermost small island bordering Australia. Geographically located at $7^{\circ} 30^{\prime}-7^{\circ} 35$ 'LS and $108^{\circ} 53^{\prime}-109^{\circ} 03^{\prime} \mathrm{BT}$. To the north of the island there is a strait known as the seal of tillers. This strait separates the island of Nusakambangan with mainland Java island, especially with city of cilacap. To the south of the island nusakambangan is an Indian ocean famous for its great waves. Nusakambangan island is about $210 \mathrm{~km}^{2}$ or about 21,000 ha. It extends from west to east. Administratively Nusakambangan island is included in the area of Tambakerja subdistrict Cilacap South, Cilacap, Central Java.

Nusaakambangan has an area of $21,000 \mathrm{Ha}$. In it there are four small conservation areas, namely Nusakambangan Barat Nature Reserve (928 ha), East Nusakambangan CA (277 ha), CA Wijayakusuma (one ha), and CA Karangbolong (0.5 ha) Its status since the Dutch era.To the north of Nusakambangan island lies Segara Anakan with a series of small islands along with swamps and mangrove forests on the southern coast of Cilacap. Segara Anakan waters is part of the Indonesian Ocean with river estuaries and the brackish forest of Cilacap and Ciamis. Together with Nusakambangan forest,SegaraAnakan and its surrounding areas constitute an ecosystem structure composed of small island ecosystem units with lowland forests in Nusakambangan, coastal and coastal, lagoon ecosystems in Segaraa nakan, mangrove swamps, both in the North coast of Nusakambangan, south coast of Cilacap and east coast of Ciamis. This environmental arrangement is influenced by the ocean waters of the Indonesian Ocean and freshwater from several watersheds such as Citanduy from the west, Cibeureum and others from the north, and the Donan River near Cilacap.

Natural panorama such as natural caves that number more than 25 and still growing and growing in terms of growth staklamit and stalatitnya, with an average depth of 3-4 meters below sea level and consists of old volcanic rock. White sand, wet tropical rain forests that are rare in Central Java, and historic buildings such as prison houses built by the Dutch, Portugal fortress, is a natural and historical potential that is very possible to be a different tour.

Nusakambangan tropical natural forests, now partially preserved as Nature Reserve (forest cover), for the conservation of germplasm, maintaining endemic species, as well as wildlife habitats such as panthers, javan hawks, langurs, pangolins, and some rare bird species.
Topography is generally hilly and bumpy, as well as slightly flat areas on the north and west ends. Pucakpeak is quite high ranging from 150-200 MASL (metres above sea level) with the highest peak reaches $190 \mathrm{~m}$ in the eastern part of the island. The area of ridge-ridge that runs along the northern part of the island consists of limestone hills, while along the southern part it consists of old volcanic rocks.

Nusakambangan until the 1980s, is a closed area, but now closely related to the utilization of natural resources. Mining of cement raw materials appears to be one of the limestone limestone factors, although rehabilitation measures have been designed and implemented. The current form of nusakambangan management consists of nature reserves, protection forests, mining areas, agricultural lands and penitentiary complexe.

\section{Limestone mining in Nusakambangan}

Limestone mining on the island of Nusakambangan has been done by PT Holcim Indonesia Tbk (formerly PT Semen Nusantara) since 1977. Holcim's mining permit area reaches 1,000 ha, but only mined about 350 ha or $0.45 \%$ of the area of Nusakambangan Island. The remaining 650 ha will be used as conservation forest.

Limestone mining on Nusakambangan Island and clay in Jeruklegi by Holcim, has legal and licensing grounds, among which, Adendum No.017 / - LCA.DIR / I / 2012 Letter of Cooperation Agreement between PTSemen Cibinong Tbk (PT Holcim Indonesia Tbk ) With the Ministry of Justice and Human Rights No: E.PL.03.06-629 0034 / Dir / XI / 2001 on Limestone Mining on Nusakambangan Island with a period of 30 years, valid from November 27, 2001 to November 26, 2031. In addition, the Decree of the Governor of Central Java Number 540/32 / - Year 2000 dated 18 September 2000 on the granting of Mining Business License (SIPD) Exploitation of Lime Stone Material to PT Semen Cibinong Tbk valid until 19 September 2023. Conservation Forest Decision Java Governor Central Number 540/11/2006 on Amendment to Decree of Central Java Governor Number 540/32/2000 concerning Provision of Mining Permit (SIPD) Exploitation of Lime Stone Material to PT Semen CibinongTbk is valid until September 19, 2023. Then Decree of Regent of Cilacap no. 545/421/19/2011 dated September 12, 2011 concerning the granting of Mining Operation Permit (IUP) of Non-Metal Mineral Production Operation to PT Holcim Indonesia Tbk valid until September 19, 2023. All mining land has been reclaimed according to the document of analysis Environmental impact (AMDAL), RPL and RKL, by closing the ex-mine area with soil, and then greening by planting Nusakambangan native plants.

Overall, limestone reserves in the SIPD area of 1,000 hectares is estimated at 290 million tons. In the former area of PT Holcim Indonesia mine is re-planted into a forest with Nusakambangan native plants. The A and B zones that are being cultivated are subdivided into quarry 
quarries. The limestone mining in Nusakambangan area begins by blowing limestone hills with dynamite that once blast is installed in about seven dots. Based on the company's warning board, the preparation siren sounded at 11.45-11.55, blasting sirens at 12.00 and 16.00 , the safe siren at $12: 15$ and $16: 15$.

\section{Issues related to the impact of limestone mining in Nusakambangan}

Exploitation of limestone in Nusakambangan has been carried out continuously with a very large amount of production. This condition leads to significant change in the topography of the mining area. Mining often substantially alters the landscape in ways that affect groundwater, surface water and enviromental resources. Streams, springs, and wetlands are often substantially altered or oven removed from the landscape. Surface mines, by their nature, results in the removal of the landscape within the footprint of the open pit. The removal of key hydrologic landscape elements, such as sinkholes, streams and springs, may result in substansial alteration of ground water flow patterns, quantity and quality.

Karst is basically an area vulnerable to environmental damage. Mining of lime in the karst area that currently becomes uncontrolled leads to environmental damage. The damage originated from the cutting down of cover vegetation to support limestone mining activities. The deforestation that occurred in the karst hills caused the area to be unable to catch the rain. Impact, the area will be dry. Reduced vegetation around the karst hills also causes a decrease in the oxygen content in the air so that the temperature in the region becomes higher. The least vegetation in the karst area also causes the soil to become increasingly unstable. The absence of a buffer / buffer in the form of trees makes the area very vulnerable to the movement of land masses, especially landslide hazards. In addition, other environmental problems that may arise are decrease in soil productivity, erosion and sedimentation, and disturbance to flora and fauna that have habitat in karst area.

Here are some of the features of the mining area on the island nusakambangan photographed from google earth.

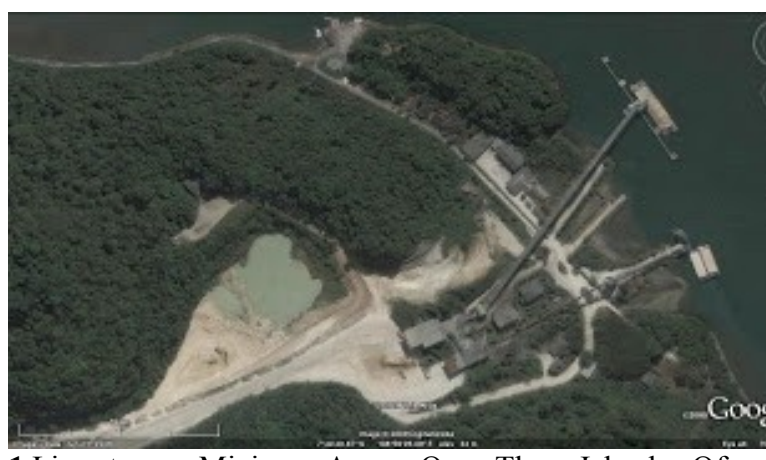

Fig 1.Limestone Mining Area On The Island Of Nusakambangan

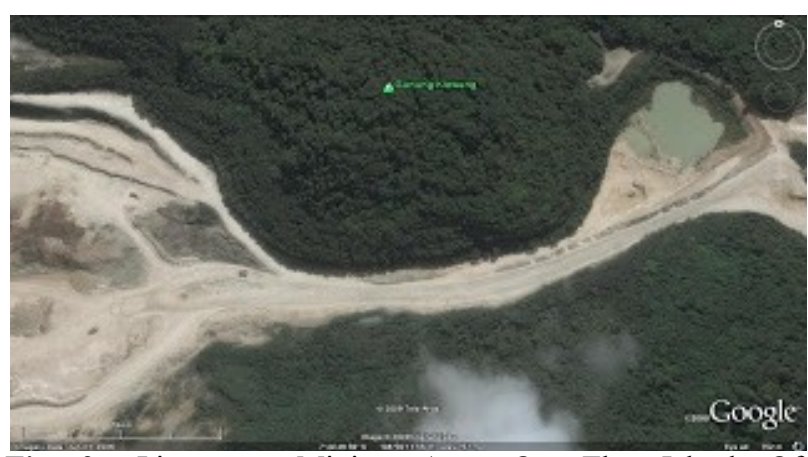

Fig 2. Limestone Mining Area On The Island Of Nusakambangan

\section{Reference}

1. Royaume du Maroc, Projet de loi no 33-13 relative aux mines. Royaume du Maroc, Ministère de l'Énergie, des Mines, de l'Eauet de l'Environnement, Département de l'Énergie et des Mines. Sater, J.N., 2010. Morocco: Challenges to Traditi, (2015)

2. K. Babi, Perceptions du développementminier durable par les acteurslocaux, gouvernementauxetindustriels au Maroc. Masters thesis, Université du Québec en AbitibiTémiscamingue, Rouyn-Noranda.

3. J.E.Tilton, Resour. Policy 22, 91-97, (1996)

4. Akcil, A., Koldas, S, J. Cleaner Prod. 14, 1139 1145, (2006)

5. Andrews-Speed, P., Ma, G., Shao, B., Liao, C., Economic responses to the closure of small-scale coal mines in Chongqing, China, (2005)

6. Azapagic, A., Resour. Policy 30, 39-54. (2004)

7. J. Cleaner Prod. 12, 639-662.

8. Burneo, M.L., Warnaars, X., Dev. Change 39, 887914, (2008)

9. J.Bhattacharya, Mineral Resour. Eng. 9, 451-464, (2000)

10. B.Bossé, B.Bussière, R.Hakkou, A.Maqsoud, M.Benzaazoua, Mine Water Environ. 32, 152-167, (2013)

11. F.Vanclay, Conceptualizing social impacts. Environ. Impact Assess. 22, 183-211, (2002)

12. Van Dam, R.A., Humphrey, C.L., Martin, P., Toxicology 181/182, 505-515, (2002)

13. D.J.Vogel, Manag. Rev. 47, 19-45.

14. Wang, Y., Shi, J., Wang, H., Lin, Q., Chen, X., Chen, Y., 2007. Ecotoxicol. Environ. Saf. 67, 7581, (2005)

15. A. Whitmore, J. Cleaner Prod. 14, 309-314.

16. Woertz, E., 2014. Mining strategies in the Middle East and North Africa. Third World Q. 35, 939957. 
17. Worrall, R., Neil, D., Brereton, D., Mulligan, D., 2009. J. Cleaner Prod. 17, 1426-1434, (2006)

18. Younger, P.L., Total Environ. 265, 309-326, (2001)
19. Dokumen Status Lingkungan Hidup Kabupaten Cilacap Tahun 2007.

20. Partomiharjo, Tukirin \& Ubaidillah, Rosichon. Daftar Jenis Flora dan Fauna Pulau Nusakambangan, Cilacap Jawa Tengah (2004) 